Teologia Praktyczna 20(2019)

doi: $10.14746 /$ tp.2019.20.04

ORCID: 0000-0002-8627-3821

BOGDAN KULIK

\title{
Czy wystarczy być dobrym człowiekiem, żeby dostać się do nieba? Przyczynek do eschatologii praktycznej
}

Z okazji XXIII wspólnego posiedzenia członków Akademii Papieskich, odbywającego się 4 grudnia 2018 roku w Watykanie pod hasłem: „Wieczność, inne oblicze życia”, papież Franciszek zwrócił się do jego uczestników z przesłaniem dotyczącym sytuacji eschatologii we współczesnym Kościele [Franciszek 2018]. Ojciec Święty przypomniał, że zagadnienia zmartwychwstania i życia wiecznego człowieka są istotnym elementem naszej wiary, ściśle związanym z prawdą o śmierci i zmartwychwstaniu Chrystusa. Na poziomie poszukiwań teologicznych, celebracji i przepowiadania, a przez to także w życiu wiernych - zwłaszcza wśród młodzieży - tematy te nie cieszą się niestety odpowiednim zainteresowaniem; według papieża, są wręcz zaniedbane. „Ma się czasami wrażenie, że ten temat jest celowo zapominany i pomijany, ponieważ na pozór jest daleki, obcy życiu codziennemu i współczesnej wrażliwości" (Franciszek 2018) ${ }^{1}$. Ten stan rzeczy, stwierdza Franciszek, powinien być zatem zmieniony. „Wyrażam życzenie, aby zarówno na poziomie teologicznym, jak i na poziomie przepowiadania, katechezy i formacji chrześcijańskiej zostało odnowione zainteresowanie i refleksja nad wiecznością, bez której wymiar teraźniejszości staje się pozbawiony ostatecznego sensu, zdolności odnowy, nadziei na przyszłość" (Franciszek 2018)2

Niniejszy artykuł jest próbą odpowiedzi na wezwanie papieża poprzez podjęcie zagadnienia, które - pomimo współczesnej niewrażliwości eschatologicznej - pojawia się dość często w rozmowach z osobami deklarującymi

${ }^{1}$ Tłum. własne.

${ }^{2}$ Tłum. własne. 
wiarę w Chrystusa, a także z uznającymi się za tzw. niewierzących ${ }^{3}$. Temat ten jest także poruszany w poważnym dyskursie teologicznym, o czym świadczą chociażby teksty kard. Józefa Ratzingera (2013) i kard. Gerharda Ludwiga Müllera (Müller i Lisicki 2018, s. 233-243, 252-253). Chodzi mianowicie o kwestię, którą można streścić pytaniem zawartym w tytule artykułu: „Czy wystarczy być dobrym człowiekiem, żeby dostać się do nieba?”. Nierzadko słyszy się bowiem, że jedynym warunkiem osiągnięcia szczęścia po śmierci jest bycie dobrym człowiekiem. W pierwszym momencie brzmi to bardzo optymistycznie, lecz sytuacja zmienia się w chwili, gdy zaczyna się stawiać pytania o znaczenie poszczególnych członów tego stwierdzenia, a mianowicie, co to właściwie znaczy: „być dobrym” i „dostać się do nieba”? Ciężar gatunkowy wskazanego problemu ujawnia się szczególnie wtedy, gdy osoby głoszące wspomnianą tezę utrzymują, że owa dobroć nie musi mieć związku z wiarą w Chrystusa. W konsekwencji głosi się, że enigmatyczne „bycie dobrym", a nie relacja z Chrystusem, staje się sposobem dostania się do nieba.

To, co zostało powiedziane do tej pory, można uznać za próbę odpowiedzi na postawione w tytule pytanie, które należałoby zaliczyć do zagadnień z dziedziny eschatologii praktycznej, rozumianej jako refleksja teologiczna nad kwestiami dotyczącymi tzw. rzeczy ostatecznych człowieka i świata, poruszanymi przez osoby spotykane przez duszpasterzy. Celem tak rozumianej eschatologii jest kształtowanie wśród ludzi zarówno wierzących, jak i deklarujących się jako niewierzący postaw i zachowań względem życia, śmierci i wieczności zgodnych z objawieniem. W tym celu stawiane pytania i głoszone opinie powinny być poddane teologicznej weryfikacji, czyli skonfrontowane z poprawną eschatologią akademicką, aby w jej świetle zostały oczyszczone $\mathrm{z}$ ewentualnych błędów. W związku z tym, w celu udzielenia odpowiedzi zgodnie z eschatologią Kościoła katolickiego, w niniejszym artykule przeanalizowano kolejno poszczególne elementy postawionego pytania. Najpierw podjęto próbę wytłumaczenia, co oznacza określenie „dobry człowiek”, a następnie, jak należy rozumieć zwrot: „dostać się do nieba”. Na koniec zaprezentowano wnioski praktyczne.

\section{I. „Dobry człowiek” - czyli właściwie kto?}

Aby zrealizować cel niniejszego artykułu, należy przede wszystkim zdefiniować pojęcie „dobry człowiek”. Istota problemu leży w tym, że określenie to

\footnotetext{
${ }^{3}$ Nawet pobieżna konsultacja materiału zawartego w Internecie potwierdza zainteresowanie tą kwestią wśród nie-teologów, osób o odmiennych światopoglądach czy różniących się deklarowaną wiarą; zob. np.: Turnau (24.01.2019); Czy nie wystarczy być dobrym czlowiekiem? (24.01.2019); Czy to możliwe, żeby «dobrzy ludzie» mogli wylądować w piekle? (24.01.2019).
} 
można zaliczyć do tzw. pojęć-worków, tzn. takich, które mają wiele znaczeń, niejednokrotnie ze sobą sprzecznych. Wszystko zależy od tego, kto i w jakim kontekście ich używa ${ }^{4}$. Można bowiem powiedzieć: dobry ojciec, dobry brat, dobra siostra. Ma się wtedy spontanicznie na myśli człowieka, który czyni realne, obiektywne dobro. W tych przypadkach czujemy, że „dobry” oznacza to, co powinien, zgodnie ze swoim sensem podstawowym. Jest to zatem określenie pozytywne. W tym miejscu należy jednak zapytać razem z Ratzingerem: „Skąd właściwie wiemy, czym jest ojcostwo, czym jest bycie bratem lub siostrą, że możemy z tymi pojęciami łączyć tak wielkie zaufanie?" (Ratzinger 1995). Inaczej mówiąc, kto ostatecznie definiuje dobroć ojca, brata i siostry? Z kim mamy porównać te osoby, by zmierzyć ich realne bycie dobrymi?

Można za Ratzingerem (2013, s. 994) przytoczyć jeszcze inny przykład: „Brzmi to ludzko i szlachetnie, gdy [...] mówi się, że chcąc się zbawić, muzułmanin musi być «dobrym muzułmaninem» (co to właściwie znaczy?), hindus dobrym hindusem i tak dalej”. Teraz, coraz wyraźniej ukazuje się niejednoznaczność pojęcia „dobry”. Sytuacja staje się jeszcze bardziej złożona, gdy wskaże się kolejne przykłady. Paradoksalnie, mówi się bowiem także tak: dobry złodziej, dobry cwaniak itd. W tych i tym podobnych przypadkach przymiotnik ,dobry” oznacza nie tyle kwalifikację moralną osoby, ile niejako jej wysoki stopień wyspecjalizowania się w dokonywaniu kradzieży czy matactwa. Można zatem powiedzieć, że w potocznym użyciu przymiotnik „dobry” wzmacnia i uwypukla treść rzeczownika, który opisuje, a nie jest nośnikiem treści „dobroci obiektywnej”.

Ratzinger (2013, s. 994) stawia problem jeszcze radykalniej i kontynuując swoje rozważania na temat bycia dobrym poszczególnych kategorii ludzi, pyta: „Czy jednak nie należałoby wtedy powiedzieć także, że kanibal musi być «dobrym kanibalem», a przekonany esesman - esesmanem w pełnym tego słowa znaczeniu? Jest jasne: coś tu się nie zgadza”. Kardynał Müller uzupełnia pytanie Ratzingera, mówiąc bez ogródek: „Kto bowiem definiuje, na czym polega dobro, czym ono jest? [...] To, co dla jednego jest dobre, dla drugiego może być złe. Dla Hitlera dobro polegało na tym, żeby Niemcy podbiły Rosję i stworzyły tam sobie przestrzeń życiową" (Müller i Lisicki 2018, s. 234-235).

Aby zatem ustalić, co naprawdę, czyli zgodnie z wolą Boga Trójjedynego, oznacza bycie dobrym człowiekiem, należy sięgnąć do objawienia. Kluczowa w wyjaśnieniu tej kwestii jest rozmowa Jezusa z bogatym młodzieńcem opisana przez Mateusza, Marka i Łukasza. „To opowiadanie oraz przypowieść o robotnikach w winnicy (Mt 20,1-16) stanowią całość i podejmują kwestię

${ }^{4}$ Podobnymi słowami-workami są: ,wieczność” i „ludzki”. Na temat słowa „wieczność” zob. Kulik (2018, s. 129). Na temat słowa „ludzki” zob. Ratzinger (2013, s. 992). 
przynależności do królestwa: czy osiąga się je na podstawie dobroci ludzkiej czy dobroci Boga?" (Leske 2000, s. 1186).

Warto przytoczyć Markową wersję wskazanej perykopy, która stała się pierwowzorem tekstów pozostałych synoptyków (Mickiewicz 2012, s. 272):

Gdy wybierał się w drogę, przybiegł pewien człowiek i upadłszy przed Nim na kolana, pytał Go: „Nauczycielu dobry, co mam czynić, aby osiągnąć życie wieczne?”. Jezus mu rzekł: „Czemu nazywasz Mnie dobrym? Nikt nie jest dobry, tylko sam Bóg. Znasz przykazania: Nie zabijaj, nie cudzołóż, nie kradnij, nie zeznawaj fałszywie, nie oszukuj, czcij swego ojca i matkę”. On Mu rzekł: „Nauczycielu, wszystkiego tego przestrzegałem od mojej młodości”. Wtedy Jezus spojrzał z miłością na niego i rzekł mu: „Jednego ci brakuje. Idź, sprzedaj wszystko, co masz, i rozdaj ubogim, a będziesz miał skarb w niebie. Potem przyjdź i chodź za Mną!”. Lecz on spochmurniał na te słowa i odszedł zasmucony, miał bowiem wiele posiadłości (Mk 10,17-21; por. Łk 18,18-22, Mt 19,16-21).

Za trafny i podstawowy wniosek z lektury powyższego tekstu można uznać komentarz Adriana Leske (2000, s. 1186-1187):

Młodzieniec sądzi, że może osiągnąć to, co w gruncie rzeczy jest egocentrycznym pragnieniem życia wiecznego, dzięki własnej dobroci. Jezus odpowiadając, odsyła go do „Jednego, który jest dobry”, do samego Boga (por. Mt 20,15); jest to [...] przypomnienie, że wszelkie działanie musi być umotywowane miłością do Boga. To w tym właśnie świetle Jezus mówi o przestrzeganiu przykazań, co stanowi podstawę związku z Bogiem i bliźnimi. Jezus przytacza drugą tablicę warunków przymierza (Wj 20,12-16; Pwt 5,16-20) i na koniec cytuje Kpł 19,18 jako streszczenie tych przykazań. Miłość bliźniego wynika z miłości Boga. O tym, że młody człowiek niewiele zrozumiał, świadczy jego stwierdzenie, że zawsze przestrzegał wszystkich przykazań. [...] Młodzieniec, o którym mowa, nie pojął, że zarówno to życie, jak i życie wieczne są darmowymi darami Boga, który jest dobry.

Na podstawie tego, co zostało powiedziane do tej pory, można więc określić, kim - według Pisma Świętego - jest dobry człowiek. To człowiek, którego zachowanie charakteryzują dwie cechy: po pierwsze - związek z Bogiem, który jest jedynym źródłem dobra (Karris 2001, s. 1090) ${ }^{5}$, a po drugie - zachowywanie się wobec innych ludzi zgodnie z Dekalogiem. Przestrzeganie Bożych przykazań jest praktycznym wyrazem prawdziwej i żywej relacji ze Stwórcą, ponieważ może być łatwo zweryfikowane, w przeciwieństwie do stopnia tylko samej wewnętrznej zażyłości z Bogiem, nawet jawnie deklarowanej (Keener 2000, s. 104). Innymi słowy: jedynie jednoczesne zachowanie obu przykazań:

\footnotetext{
${ }^{5} \mathrm{Na}$ temat dobroci Boga jako wzoru dobroci ludzkiej zob. Ratzinger (1995, s. 37-39).
} 
„przykazania miłości Boga i bliźniego prowadzi do życia wiecznego" (Karris 2001, s. 1089). Widać wyraźnie, że istotną rolę pełni w tym stwierdzeniu spójnik ,i”.

\section{Co to znaczy „dostać się do nieba"?}

Najpierw warto odpowiedzieć na pytanie, czym jest niebo, by następnie zastanowić się, co oznacza zwrot „dostać się”. Już na podstawie samej lektury omawianej perykopy można zauważyć, że niebo musi być rzeczywistością godną najgłębszych ludzkich pragnień. To z jego powodu bogaty młodzieniec przychodzi do Jezusa, pytając o sposób jego osiągnięcia. Mimo iż pyta o życie wieczne $^{6}$, kontekst rozmowy nie pozostawia wątpliwości, że jest ono synonimem nieba ${ }^{7}$. Poza tym, w niebie czeka na człowieka obiecany przez Jezusa skarb, dla osiągnięcia którego należy nie tylko wypełniać Boże przykazania, lecz także dobrowolnie zrezygnować z ziemskiego bogactwa ${ }^{8}$.

W celu udzielenia odpowiedzi na postawione w tytule pytanie warto jednak głębiej zastanowić się, co oznacza pojęcie „niebo”. Szczególnie cenna jest w tym względzie refleksja Ratzingera zawarta w jego dwóch tekstach: w artykule pt. Niebo (Ratzinger 2014 b, s. 305-308) i w podręczniku do eschatologii pt. Eschatologia - śmierć i życie wieczne (Ratzinger 2014 a, s. 25-257) ${ }^{9}$. Niemiecki teolog w obu tekstach thumaczy, jak należy poprawnie rozumieć metaforę nieba, wskazując, czym ono nie jest, a czym jest.

Przyszły papież przede wszystkim zaznacza, że pytanie o niebo nie jest przejawem „egzaltowanej fantazji”, ale pytaniem o „ową ukrytą Obecność, która naprawdę pozwala nam żyć, a którą jednak ciągle pozwalamy sobie przesłaniać i odbierać przez to, co powierzchowne” (Ratzinger 2014 a, s. 219). Doświadczenie jej w pełni jest zatem możliwe dopiero w eschatologicznej

${ }^{6} \mathrm{Na}$ temat treści tego pojęcia z punktu widzenia egzegezy biblijnej zob. np.: Mickiewicz (2012, s. 275); Paciorek (2008, s. 265).

${ }^{7}$ Na temat związku między pojęciami „niebo” i ,życie wieczne” zob. np.: Nitrola (2010, s. 408-409 ; 412-415; 471-504).

${ }^{8}$ „«Idź, sprzedaj wszystko, co masz, i rozdaj ubogim». Polecenie Jezusa należy rozumieć jako wymóg względem konkretnej osoby, nie zaś jako ogólną zasadę życia chrześcijańskiego czy wyraz doskonalszej duchowości” (Harrington 2001, s. 1016). Istnieje także inna interpretacja: „Wartość pouczająca całego opowiadania jest taka sama u wszystkich trzech synoptyków: chcąc osiągnąć pełnię doskonałości moralnej, trzeba się pozbyć wszystkiego i pójść za Jezusem. Posiadanie bogactw i własnej rodziny nie tyle może uniemożliwia wprost zdobycie doskonałości, ile raczej czyni niemożliwym pójście za Chrystusem, a owo naśladowanie Chrystusa zdaje się być częścią nieodłączną wspomnianej już doskonałości, stanowiąc równocześnie rękojmię najpewniejszą wejścia do królestwa Bożego" (Romaniuk i in. 1999, s. 224).

${ }^{9}$ Chodzi przede wszystkim o paragraf pt. Niebo (s. 219-222), który stanowi zmodyfikowaną formę wyżej wskazanego artykułu pod tym samym tytułem. 
przyszłości. Dalej czytamy, że niebo nie jest określeniem w pierwszym rzędzie przestrzennym, choć z przestrzenią pozostaje w ścisłym, aczkolwiek dla nas nieprzeniknionym, związku (Ratzinger 2014 a, s. 160; 221). Jest ono przede wszystkim „rzeczywistością osobową” (Ratzinger 2014 a, s. 219). Dlatego Ratzinger może powiedzieć: „Nie jest ono jakimś ahistorycznym miejscem «do którego» się wchodzi, ale opiera się na ugruntowanym w Chrystusie byciu jednością Boga i człowieka, tak, że można powiedzieć, iż być w niebie znaczy być razem z wywyższonym Chrystusem" (Ratzinger 2014 b, s. 305). Istotę nieba stanowi więc ,intymność z Bogiem” (Ratzinger 2014 b, s. 306) ${ }^{10}$. Ostatecznie niemiecki teolog konkluduje zdecydowanie: „Chrystus jest «tym» niebem”, „Raj otwiera się w Jezusie. Zależy od Jego Osoby. [...] Sam Chrystus jest Rajem, światłem, świeżą Wodą i bezpiecznym Pokojem, na które ukierunkowane są oczekiwanie i nadzieja ludzi” (Ratzinger 2014 a, s. 222; 131).

Wynika z tego, że niebo ma przede wszystkim wymiar chrystologiczny i wszystkie inne jego wymiary (teologiczny, antropologiczny, eklezjologiczny i kosmologiczny) mogą być rozpatrywane tylko jako jego konsekwencje. Owo przebywanie z Bogiem w Chrystusie jest „ostatecznym spełnieniem ludzkiej egzystencji przez spełnioną miłość" (Ratzinger 2014 a, s. 219), jest pełnią szczęścia, czyli, wracając do języka perykopy o Jezusie i bogatym młodzień$\mathrm{cu}$, jest obiecanym skarbem.

Biorąc po uwagę kontekst wypowiedzi Jezusa, który mówi o otrzymaniu skarbu w niebie po uprzednim wypełnieniu przykazań i uwolnieniu od bogactw, można stwierdzić, że skarb ten w pewnym sensie jest nagrodą, na którą człowiek zasługuje poprzez swoje życie na ziemi. Niebo staje się w ten sposób „nagrodą za zasługi” dobrego człowieka (Mickiewicz 2012, s. 276). Oba pojęcia („nagroda” i ,zasługa”) występują także w Piśmie Świętym i Tradycji. Jak je rozumieć?

Do udzielenia odpowiedzi niewystarczające jest studium samego tekstu biblijnej perykopy o bogatym młodzieńcu. W polskim tłumaczeniu odnajdujemy zwroty: „otrzymać” życie wieczne (Mt 19,16); „osiągnąć” życie wieczne (Mk 10,17; Łk 18,18) ${ }^{11}$; a nawet ,zdobyć” życie wieczne (Mk 10,17) ${ }^{12}$. W oryginale greckim występują natomiast leksemy: $\sigma \chi \tilde{\omega}$ (od है $\chi \omega-$ mam, posiadam) (Mt 19,16) ${ }^{13} ; \kappa \lambda \eta \rho o v o \mu \eta ́ \sigma \omega(\operatorname{od~\kappa \lambda \eta \rho ovo\mu \varepsilon ́\omega ~-~odziedziczam,~otrzymuję~w~po-~}$

${ }^{10}$ Warto zauważyć za Keenerem (2000, s. 640), że „«Niebo» było powszechnie używanym przez Żydów określeniem «Boga» (podobnie jak w Łk 15,21)”.

${ }_{11}$ Pismo Święte Starego i Nowego Testamentu w przektadzie z języków oryginalnych (Biblia Tysiąclecia) (2003) $)^{5}$; Biblia Jerozolimska (2006). Por. Pismo Święte Starego i Nowego Testamentu. Najnowszy przekład z języków oryginalnych z komentarzem (Biblia Paulistów) (2009).

${ }^{12}$ Pismo Święte Starego i Nowego Testamentu w przekładzie z języków oryginalnych ze wstępami i komentarzami (Biblia Poznańska). Nowy Testament (1975).

${ }^{13}$ Oznacza posiadanie pewnych łask, w tym przypadku życia wiecznego. Por. Grecko-polski Nowy Testament. Wydanie interlinearne z kluczem gramatycznym, z kodami Stronga i Popowskiego 
siadanie od kogoś) (Mk 10,17; Łk 18,18) ${ }^{14}$. Na podstawie analizy form polskich i greckich określeń sposobu wchodzenia w posiadanie życia wiecznego, można stwierdzić ich swoistą niejednoznaczność. Raz bowiem akcentują one wymiar daru (otrzymywać, odziedziczać), innym razem wynik ludzkiego wysiłku (osiągnąć, zdobyć), a czasem wyrażają po prostu stan, bez precyzowania sposobu jego osiągniecia (posiadać, uczestniczyć, mieć) ${ }^{15}$. Nadal więc nie wiadomo, w jaki sposób człowiek dostaje się do nieba: czy je zdobywa, czy otrzymuje. Jeśli uznać, że niebo jest jedynie nagrodą i zapłatą za zasługi człowieka na ziemi, wtedy oznaczałoby to, iż Bóg jest zmuszony dać nam życie wieczne. Byłoby to jednak absurdem, ponieważ pozbawiałoby Go wolności, a przez to i boskości.

Trafnie wskazane wątpliwości rozwiewa Ratzinger. Niebo jest „,nagrodą" - thumaczy niemiecki teolog - ,w znaczeniu odpowiedzi na «tę» właśnie drogę, na «to» właśnie życie, na «tego» właśnie człowieka, ze wszystkim, co w życiu przecierpiał i zdziałał” (Ratzinger 2014 a, s. 220). Niebo jest „zasługą" człowieka, to znaczy Bożą odpowiedzią na wolną życiową decyzję każdej osoby (Ratzinger 2014 b, s. 307). Mówiąc inaczej, niebo nie jest narzuconą przez Boga autorytatywnie i automatycznie jednakową dla wszystkich formą szczęścia, ale człowiek ma realny wpływ na jego kształt poprzez swoje wolne otwarcie się na Boga. Bycie człowieka z Bogiem w Chrystusie (bycie w niebie) nie powoduje więc zatracenia tożsamości człowieka. Każdy pozostaje w tej relacji sobą i nie rozpływa się w Bogu jak kropla w oceanie, której nie da się już nigdy odróżnić od otaczającej jej głębi wód. Niebo nie powoduje zatem degradacji ludzkiego ,ja”, lecz jego oczyszczenie uzdalniające do realizacji pełni swoich możliwości. Jeśli tak jest rzeczywiście, wynika $\mathrm{z}$ tego następujący wniosek: każdy przeżywa relację z Bogiem na swój własny i niepowtarzalny sposób. Każdy bowiem wnosi całego siebie, całą historię swojego życia do nieba. Stąd bierze się w niebie „stopniowanie szczęśliwości, które [...], należy rozumieć w ten sposób, że każdy według swej miary jest całkowicie wypełniony, ale że miary poszczególnych ludzi są różne" (Ratzinger 2014 b, s. 307). Jednocześnie jednak trzeba podkreślić, że pojęcia „,nagrody” i „zasługi” nie oznaczają w żadnym wypadku, że niebo jest tylko i wyłącznie owocem wysiłku człowieka, któremu należy się zasłużona zapłata jako nagroda. Taka

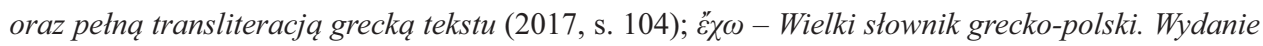
z petna lokalizacja greckich haset, kluczem polsko-greckim oraz indeksem form czasownikowych (1997, s. 250, hasło: 2189 g).

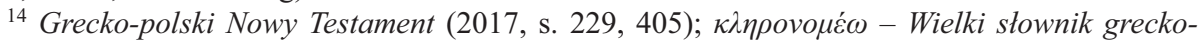
-polski (1997, s. 339, hasło: 2805).

${ }^{15}$ Tę niejasność podtrzymuje także zdanie Keenera, który tłumaczy w komentarzu do Markowej wersji opowiadania: „Zwrot «osiągnąć (dosł. odziedziczyć) życie wieczne» oznaczał uczestniczenie w życiu przyszłego świata - królestwie Bożym” (Keener 2000, s. 104). 
opinia jest szeroko rozpowszechniona wśród wiernych i wyraża się w różnego rodzaju sposobach ,zasługiwania” na niebo, a niekiedy w postawie przeciwnej: w buncie wobec domniemanej konieczności ,zapracowywania” na raj.

Zawsze i niezmiennie niebo pozostaje darem Bożej miłości, jest wolnym pochyleniem się kochającego Boga, czyli łaską (Ratzinger 2014 a, s. 220; 2014 b, s. 306-307). Ratzinger przypomina, że , istotą tego, co w górze, a co nazwaliśmy niebem, jest to, że można je tylko otrzymać, tak jak piekło można tylko samemu sobie dać" (Ratzinger 1996, s. 307).

Podsumowując, trzeba więc powiedzieć, że na kształt mojego nieba wpływają jednocześnie i nierozdzielnie dwa elementy: nieskończony Boży dar miłości i sposób mojego przyjęcia tego daru. Powtórzmy: niebo, czyli wspólnota z Bogiem w Chrystusie, to niezasłużony dar, który otrzymuje się za darmo, lecz by go posiadać, należy dobrowolnie go przyjąć. Jedynie owo przyjęcie można otwarcie uznać za osiągniecie, zdobycie, pójście, dostanie się do nieba. Nigdy tylko o własnych siłach, nigdy ,z automatu”, jakby sam fakt czynienia dobra przenosił nas do nieba. Arcybiskup Grzegorz Ryś (2016, s. 264) ujmuje to bardzo rzeczowo:

Żadne czynione przez nas dobro nie czyni nas nieśmiertelnymi, nie potrafi nas przenieść poza granicę śmierci [...]. Nie chodzi o to, że dobro czy mądrość są nieważne. Są ważne, ale to nie one przeprowadzają nas przez śmierć. Chrześcijaństwo w żadnym wymiarze nie jest autosoteriologią. Tym, który nas zbawia, jest Bóg. Tym, co nas przeprowadza przez granicę śmierci, jest nasza osobista relacja z Jezusem Chrystusem.

Warto na zakończenie obecnej refleksji dodać, że cennym rozwinięciem myśli o niebie jako darze Bożej miłości jest rozważanie Ratzingera na temat dziecięctwa Bożego. To właśnie bycie jak dziecko, jak Syn wobec Boga Ojca, powinno być fundamentalną postawą człowieka, który pragnie doświadczyć nieba.

Człowiek chce być Bogiem [...]. Chce on boskości i ostatecznie nie jest w tym bez racji, ale chce tego na sposób Prometeusza, przywłaszczając ją sobie przemocą. Jednakże nie jest on Bogiem. [...] Nie Prometeusz, ale posłuszeństwo ukrzyżowanego Syna jest miejscem, w którym ujawnia się stawanie się człowieka Bogiem. Człowiek może stać się „Bogiem”, jednak nie przez to, że sam się nim czyni, ale jedynie przez to, że stanie się ,,synem” [...]. Bycie Bogiem, „emancypacja" do królestwa Bożego, które usuwa wszelkie wyobcowanie i zniewolenie, nie jest czymś wyprodukowanym, ale darem, podobnie jak czysta miłość z samej swej istoty może być tylko darem (Ratzinger 2014 a, s. 83-85) ${ }^{16}$.

${ }^{16}$ Ratzinger często porusza ten wątek w swoich tekstach; por. tenże (1995, s. 73); Benedykt XVI (2012, s. 139). 
Kardynał Müller wyraża tę sama prawdę jeszcze prościej: „Człowiek może mieć udział w łasce odkupienia Chrystusa [...] nie dzięki samej dobrej woli, lecz dzięki łasce jedynego Pośrednika między Bogiem i ludźmi. To ona otwiera mu niebo" (Müller i Lisicki 2018, s. 253).

\section{Próba odpowiedzi na pytania i wnioski praktyczne}

Zanim zostanie podjęta próba udzielenia odpowiedzi na zadane w tytule artykułu pytanie, należy podsumować dotychczasową analizę omawianego zagadnienia. Przede wszystkim trzeba stwierdzić, iż na podstawie lektury perykopy o Jezusie i bogatym młodzieńcu widać jasno, że prawdziwego, pełnego znaczenia pojęcia „dobry” nie można szukać bez odniesienia go do Boga objawiającego się w Jezusie Chrystusie, a w konsekwencji bez odniesienia do danych przez Niego przykazań. Tylko te dwa elementy, tzn. relacja miłości do Boga na wzór relacji Jezusa do Ojca i relacja miłości do ludzi kształtowana według Dekalogu wypełniają prawdziwą treścią pojęcie „dobry człowiek”.

Należy z mocą podkreślić, że obydwa wskazane elementy muszą zawsze występować razem, gdyż ze swej natury przynależą do siebie. Tylko szczera, nawet jeśli na ziemi zawsze jeszcze niedoskonała, miłość człowieka do Boga wyrażająca się w synowskim otwarciu, jest fundamentem uzdalniającym do prawdziwej miłości względem ludzi, najpełniej wyrażającej się w przestrzeganiu przykazań Bożych. Mówiąc prościej: dobry człowiek - w prawdziwym, pełnym tego słowa znaczeniu - to ten, który posiada wiarę ${ }^{17} \mathrm{w}$ Boga objawionego w Jezusie Chrystusie i szczerze stara się zachowywać wszystkie Jego przykazania ${ }^{18}$. Oznacza to, że za nieprawdziwe, czyli niezgodne z Bożym objawieniem, należy uznać stwierdzenie: można być dobrym człowiekiem, dobrowolnie odrzucając Chrystusa, byleby czynić dobro ${ }^{19}$. Nieprawdą jest także, że można być dobrym człowiekiem mimo lekceważenia niektórych (choćby

17 Słowo „wiara” jest użyte w znaczeniu gestu otwarcia się na dar miłości Boga w Jezusie Chrystusie. Na ten temat zob. Ratzinger (2013, s. 992-993).

${ }^{18}$ Trzeba w tym miejscu zaznaczyć, że w niniejszych rozważaniach nie zamierza się dotykać problemu dobroci osób należących do innych tradycji religijnych, czyli tzw. kwestii możliwości zbawienia wyznawców innych religii i tych, którzy bez własnej winy nie poznali Chrystusa. Jest to bowiem zagadnienie wymagające osobnego studium. Prezentowane rozważania odnoszą się do współczesnej sytuacji w Polsce, gdzie wciąż istnieje powszechna możliwość poznania Chrystusa i Dekalogu.

${ }^{19}$ Kardynał Müller przypomina, że odrzucając konieczność wiary w Boga do zbawienia i głosząc, że wystarczy być dobrym człowiekiem, rozpowszechnia się tzw. ,naturalizację, jeśli tak można powiedzieć, całej istoty człowieka". Jej propagatorami byli m.in. filozofowie oświecenia, którzy głosili np. że ,wystarczy, aby suma dobra wynikająca z czynów człowieka była większa niż suma zła” (Müller i Lisicki 2018, s. 233). 
jednego) przykazań Dekalogu ${ }^{20}$. Nie wystarczy więc jakaś „,nieokreślona ufność" w Boga czy enigmatyczna ,dobra wola" "21. Uznając takie i tym podobne opinie za prawdziwe, pojęcie „dobry człowiek” staje się wspomnianym workiem wypełnionym subiektywnymi opiniami, a nie prawdziwą treścią.

Opinie te nie stają się prawdziwe, nawet jeśli zostają poparte rzekomą zgodnością z własnym sumieniem osoby, która je wypowiada. Owo czynienie „zgodnie z własnym sumieniem” można uznać za inny sposób ujęcia twierdzenia „być dobrym człowiekiem”. Zdarza się bowiem słyszeć taką oto tezę: jestem dobrym człowiekiem, ponieważ żyję zgodnie z własnym sumieniem. Jednak w tym wypadku należy zadać pytanie podobne do pytania o znaczenie słowa „dobry”, a mianowicie: Co oznacza „sumienie”? By nie wdawać się w zbyt długą analizę, warto posłużyć się odpowiedzią udzieloną przez Ratzingera (2013, s. 995):

Jeżeli sumieniem usprawiedliwiamy wierne trzymanie się jakiegoś systemu, to przez „sumienie” rozumiemy oczywiście nie wspólny wszystkim głos Boga, lecz refleks społeczny, wyższe , ja” danej grupy. Czy jednak człowiek musi zachowywać to wyższe ,ja”, czy też powinien je usunąć, ponieważ stoi na drodze rzeczywistemu wezwaniu kierowanemu do człowieka i błędnie się z nim utożsamia? Samo sumienie, to rzeczywiste, jedyne domagające się posłuszeństwa, nie mówi przecież każdemu czegoś innego [...]. Życie zgodne z własnym sumieniem nie jest zamykaniem się w swoim tak zwanym przekonaniu, lecz podporządkowaniem się temu wezwaniu, które dochodzi do każdego człowieka: wezwaniu do wiary i miłości ${ }^{22}$.

${ }^{20}$ „Dekalog stanowi organiczną całość. Każde jego «słowo» odsyła do każdego z pozostałych i do wszystkich razem; wszystkie wzajemnie się warunkują. Dwie tablice Dekalogu wyjaśniają się nawzajem; stanowią one organiczną jedność. Przekroczenie jednego przykazania jest naruszeniem wszystkich pozostałych. Nie można okazywać czci drugiemu człowiekowi i zarazem nie czcić Boga, jego Stwórcy. Nie da się wielbić Boga, nie miłując wszystkich ludzi, Jego stworzeń. Dekalog łączy życie teologalne i społeczne człowieka” (KKK, nr 2069). Więcej na temat Dekalogu zob. Gądecki i Jędraszewski (2016).

${ }^{21}$ „Dzisiaj nie mogą nam wystarczyć wszystkie te odpowiedzi, które zbawienie «innych» sprowadzają tylko do przypisywania im «pragnienia przynależności do Kościoła», nierzadko utożsamiane z bliżej nieokreśloną ufnością czy dobrą wolą. Nie chcemy przez to powiedzieć, że refleksje te są pozbawione sensu. Są one tylko niewystarczające i niewątpliwie łatwo zbliżają się do mentalności pelagiańskiej, dla której dla zbawienia człowieka wystarczająca byłaby w końcu dobra wola. Dzisiaj zwłaszcza oczywiste dla nas musiałoby być to, jak niewystarczająca jest do zbawienia człowieka sama «dobra wola», jak bardzo wskazywanie na dobrą wolę jest czczą pociechą, która sankcjonuje istniejący stan rzeczy i w niczym się nie przyczynia do wyzwolenia człowieka. [...] Jasny się staje zarówno nieograniczony zasięg zbawienia (powszechność jako nadzieja), jak i konieczność wydarzenia Chrystusa i wiary (powszechność jako wymóg)" (Ratzinger 2013, s. 990-991). Na temat niebezpieczeństwa pelagianizmu dziś zob. GE $(35,47-62)$.

${ }^{22}$ W tym samym duchu na temat sumienia zob. Müller (2018, s. 9). 
Właśnie te dwie postawy człowieka - wiara i miłość - i tylko one, tworzą podstawowe prawo chrześcijaństwa, a zatem są istotą bycia dobrym człowiekiem.

Także analiza pojęcia „niebo" w świetle objawienia nie pozostawia żadnych wątpliwości co do tego, że nie można w nim się znaleźć, lekceważąc Chrystusa. To oczywiste, zważywszy na fakt, że niebo - to Chrystus, a być w niebie - to być w pełni zjednoczonym z Chrystusem. Nie można zatem być z Nim, lekceważąc Go. To oczywista sprzeczność. Nawet jeśli ktoś wysunąłby zarzut, iż jest to tylko chrześcijańska wizja nieba, że niebo może wyglądać inaczej, to trzeba od razu przypomnieć słowa św. Piotra o Jezusie Chrystusie Nazarejczyku: „Nie ma w żadnym innym zbawienia, gdyż nie dano ludziom pod niebem żadnego innego imienia, w którym moglibyśmy być zbawieni” (Dz 4,12).

Nie istnieje żadne ,inne niebo”, niejako paralelne do nieba-Chrystusa, nieba-z-Chrystusem. Jeśli ktoś wyraża taki pogląd, to nie robi niestety nic innego, jak tylko projektuje własne, subiektywne pragnienia na obraz życia po śmierci, czyli wpada w pułapkę myślenia mitycznego, mimo że właśnie o to wielokrotnie oskarżany jest Kościół i jego eschatologia ${ }^{23}$. Tymczasem przeciw mitycz$n^{n e m u}{ }^{24}$, czyli wymyślonemu, zaprojektowanemu przez ludzi, a nie objawionemu dobrowolnie przez Boga obrazowi życia wiecznego, Kościół występuje od samego początku swojego istnienia (por. 2 P 1,16; Keener 2000, s. 564; Stählin 1957, s. 791). Warto zauważyć, że znaczenie mitycznego obrazu bogów poddawali krytyce już także przedstawiciele tzw. greckiego oświecenia ${ }^{25}$.

Mówiąc w jeszcze inny sposób: każdy, prędzej czy później, spotka Chrystusa (por. Ap 1,7); przed Nim zegnie się każde kolano, bez wyjątku (por. Flp 2,9-11). W ramach obecnej refleksji nie można ocenić, na ile trafna jest intuicja średniowiecznego autora dzieła o sztuce dobrego umierania, który dopuszczał możliwość ukazania się Chrystusa każdemu człowiekowi tuż przed śmiercią (da Lucca 1616, s. 61-62). Jest jednak pewne to, że tylko dobrowolne przyjęcie propozycji bycia z Chrystusem, a przez to z całą Trójcą Przenajświętszą, daje możliwość przebywania w niebie. Nawet jeśli ten wolny wybór będzie skażony egoizmem, to spotkanie ze Zbawicielem oczyści ludzkie serce

23 „Dziewiętnastowieczna krytyka religii tłumaczyła powstanie wszelkich systemów religijnych tym, że ludzie to, co dla nich najlepsze i najpiękniejsze, sytuowali w niebie, aby uczynić sobie świat znośniejszym. Ale kiedy przenieśli do nieba to, co jest tylko czymś ich własnym, nazywało się to Zeus i przejmowało grozą. Ojciec biblijny nie jest niebiańską repliką ojcostwa ludzkiego, lecz stanowi coś nowego, jest Boską krytyką ludzkiego ojcostwa. Bóg ustanawia własną miarę" (Ratzinger 1995, s. 39).

${ }^{24}$ „Słowo przetłumaczone jako «mity» było zwykle używane w znaczeniu negatywnym, na określenie zmyślonych opowieści, np. oszczerczych i fałszywych relacji o bogach. Przeciwieństwem «mitów» były wiarygodne relacje" (Keener 2000, s. 564). Por. Stählin (1957, s. 788).

${ }^{25}$ Ratzinger (2014 a, s. 93-95) wspomina o Homerze, sofistach, Arystotelesie i Platonie. 
(na tym polega czyściec) i ostatecznie zakończy się pełną z Nim wspólnotą miłości (na tym polega niebo) ${ }^{26}$. Szczęście osiągnie swoją pełnię, gdy Bóg będzie „wszystkim we wszystkich” (por. 1 Kor 15,28), gdy „na końcu czasów Pan przekaże Bogu Ojcu królestwo i przedstawi Mu wszystkich, którzy żyli zgodnie z przykazaniem miłości” (Benedykt XVI 2012).

W tym momencie można wreszcie spróbować sformułować pełną odpowiedź na pytanie: Czy wystarczy być dobrym człowiekiem, żeby dostać się do nieba? Mówiąc krótko: To zależy. To zależy od tego, co rozumiemy pod określeniem „dobry człowiek”. Jeśli chodzi o człowieka nieodrzucającego Chrystusa i uczciwie starającego się żyć według całego Dekalogu, to odpowiedź brzmi: Tak, wystarczy być dobrym człowiekiem. Jeśli jednak tzw. dobry człowiek miałby być osobą, która czyni jakieś dobro obiektywne, nawet bardzo wielkie, lecz jednocześnie świadomie odrzuca Chrystusa, co ostatecznie przejawia się w lekceważeniu choćby jednego przykazania Dekalogu, to w ten sposób osoba ta sama zbacza z drogi do nieba. Zbacza tym mocniej, im świadomiej pomija w swojej dobroczynności Pana i Jego prawo. Jakże mogłaby taka osoba dojść do nieba, a właściwie - przyjąć niebo, jeśli je lekceważy, bo przecież niebo to Chrystus ${ }^{27}$. To prawda, że ostatecznie tylko Chrystus zna serce człowieka i wszystkie motywy jego działania ${ }^{28}$. Nie oznacza to przecież, że obserwując czyny i słowa konkretnej osoby, nic nie można powiedzieć o jego stosunku do Boga i Jego prawa (Kupczak 2018, s. 58). Sam Chrystus przypomniał że: „Kto ma przykazania moje i zachowuje je, ten Mnie miłuje. [...] Jeśli Mnie kto miłuje, będzie zachowywał moją naukę, a Ojciec mój umiłuje go, i przyjdziemy do niego, i będziemy u niego przebywać. Kto Mnie nie miłuje, ten nie zachowuje słów moich" (J 14,21.23-24).

${ }^{26}$ „Kościół wierzy, że jeżeli mimo wszystko w ostatniej chwili życia [człowiek] chwyta się Bożego miłosierdzia, może zostać ocalony i ostatecznie dopuszczony do wiecznej wspólnoty z Bogiem, jednak Bóg nie unieważnia osobowych konsekwencji dokonanego zła. Bolesny proces dojrzewania do nieba dla kogoś, kto przed swoją śmiercią mimo swoich licznych grzechów pokornie zwrócił się do Boga o miłosierdzie; proces, który w nauce Kościoła nosi nazwę czyśćca i który należy liczyć nie tyle czasem, ile raczej intensywnością, nie zostanie nikomu zaoszczędzony" (Machinek 18.02.2019).

27 „Każdy świadomy i dobrowolny czyn ma nie tylko swoje zewnętrzne konsekwencje, ale także wpływa na wewnętrzną kondycję tego, kto go dokonuje. Kto świadomie i dobrowolnie czyni zło, w jakimś stopniu czyni siebie samego niezdolnym do wiecznego życia z Bogiem" (Machinek 18.02.2018).

${ }^{28}$ „Ostatnie słowo należy do Boga, którego czcimy zarówno jako Miłosiernego Ojca, jak i jako Sprawiedliwego Sędziego. Czyny człowieka wynikające z jego wewnętrznego nastawienia są istotne i będą decydowały o wiecznym losie człowieka, jednak jedynie Bóg zna tajniki ludzkiego serca i wie, ile w tych czynach było złej woli, i świadomego przekraczania przykazań, ile zaciemnienia, ile wcześniejszych ran, zgorszeń i rozczarowań, które oddzielały od Bożej drogi i zniechęcały do niej" (Machinek 18.02.2018). 
Warto na koniec podjąć jeszcze próbę przedstawienia dwóch wniosków praktycznych i wyrazić je w sposób pozytywny i optymistyczny, aby choć w części odpowiedzieć na wezwanie papieża Franciszka, który prosi, by współczesna eschatologia przekazywała obraz ,pociągający” życia wiecznego (Franciszek 2018). Spróbujmy wyrazić to w następujący sposób:

1) Ratzinger (2014 a, s. 219) przypomina, że „człowiek jest w niebie wówczas i w takim stopniu, w jakim jest przy Chrystusie". Oznacza to, że człowiek znajduje się na ziemi na drodze do nieba wówczas i w takim stopniu, w jakim czyni obiektywne dobro, nie lekceważąc jednocześnie świadomie i dobrowolnie osoby Chrystusa i Dekalogu. Przypomina o tym Sobór Watykański II w Konstytucji dogmatycznej o Kościele Lumen Gentium:

Nie odmawia też Opatrzność Boża koniecznej do zbawienia pomocy takim, którzy bez własnej winy w ogóle nie doszli jeszcze do wyraźnego poznania Boga, a usiłują nie bez łaski Bożej, wieść uczciwe życie. Cokolwiek bowiem znajduje się w nich z dobra i prawdy, Kościół traktuje jako przygotowanie do Ewangelii i jako dane im przez Tego, który każdego człowieka oświeca, aby ostatecznie posiadł życie (LG 16) ${ }^{29}$.

Kluczowe znaczenie w ocenie, na którym etapie tej drogi dobry człowiek się znajduje, ma zatem poziom świadomości i dobrowolności wyboru Chrystusa i Jego przykazań. Ostatecznie i w pełni może ocenić to tylko Bóg.

2) Życiowe doświadczenie uczy, że człowiek jest istotą omylną. Oznacza to między innymi, iż nawet gdy jest przekonany, że czyni w danym momencie jakieś konkretne dobro, po głębszej analizie może uznać, że wcale tak nie jest i myli się w ocenie „dobroci” danego czynu. Z tego powodu oznaką mądrości jest robienie wszystkiego „na oczach Chrystusa”, co konkretnie oznaczałoby konfrontowanie czynionego dobra z Jego wolą wyrażoną w Dekalogu wyjaśnianym w Kościele. Takie postepowanie pozwala na dwie rzeczy. Po pierwsze, pomaga odrzucić jako fałszywe pozorne dobro, czyli to, co jest sprzeczne z Bożymi przykazaniami. Po drugie, pomaga ucieszyć się z tych działań, które w świetle Bożej nauki są dobre. To z kolei może stać się motywacją do wzrastania $\mathrm{w}$ byciu prawdziwie dobrym człowiekiem. Nie ma potrzeby bać się odkrywania przed Panem czynionego dobra i konfrontowania go z Dekalogiem, nawet jeśli wydaje się ono jeszcze bardzo małe i przesycone egoizmem. Chrystus nie odbierze nikomu uczynionego dobra, ale oczyści je i pomnoży. „On niczego nie zabiera, a daje wszystko. Kto oddaje się Jemu, otrzymuje stokroć

${ }^{29}$ Ratzinger (2013, s. 988) ujmuje to tak: „Także według Vaticanum II nie ulega i nie może ulegać wątpliwości, że tylko Chrystus jest drogą, jednak z tego nie wynika, że wszystko - co jak się wydaje jest poza Chrystusem - jest tylko bezdrożem; wszystko, co jest drogą poza Nim, jest nią ze względu na Niego, a więc do niego należy, jest drogą Drogi”. 
więcej” (Benedykt XVI 2005). Kto oddaje się Jemu, otrzymuje Jego samego, czyli niebo!

\section{STRESZCZENIE}

Według diagnozy postawionej przez papieża Franciszka, zainteresowanie eschatologią na poziomie akademickim i duszpasterskim przeżywa kryzys. Ojciec Święty wyraził swoja opinię przy okazji XXIII wspólnego posiedzenia członków Akademii Papieskich zgromadzonych 4 grudnia 2018 roku w Watykanie, które odbyło się pod hasłem: „Wieczność, inne oblicze życia”. Jednakże można zauważyć, że pewne problemy dotyczące związku życia doczesnego i wiecznego wciąż nurtują współczesnego człowieka i skłaniają do stawiania pytań o jego los po śmierci. Artykuł jest próbą odpowiedzi na jedno z takich pytań: „Czy wystarczy być dobrym człowiekiem, żeby dostać się do nieba?". Prezentowane rozważania mają na celu stać się przyczynkiem do eschatologii praktycznej. Oznacza to, że poprzez teologiczną refleksję nad treścią pojęć: „dobry człowiek” i „dostać się do nieba” pragnie się doprowadzić do sformułowania odpowiedzi i wskazania praktycznych wniosków kształtujących właściwe postawy wobec życia i wieczności.

Stowa kluczowe: Jezus Chrystus; eschatologia; niebo; dobry człowiek; sumienie

\section{IS IT ENOUGH TO BE A GOOD PERSON TO GET TO HEAVEN? A CON- TRIBUTION TO PRACTICAL ESCHATOLOGY}

\section{SUMMARY}

According to the diagnosis posed by Pope Francis, interest in eschatology, on both the academic and pastoral level, is going through a crisis. The Holy Father expressed his opinion on the occasion of the $23^{\text {rd }}$ public session of the Pontifical Academies that took place on 4 December 2018 in the Vatican. The leading theme was: „Eternity, the other face of life". However, it can be noted that there are some problems regarding the relationship of temporal and eternal life, which still bother modern man and incline him to pose questions about his fate after death. The article is an attempt to answer one of these questions: is it enough to be a good man to get to Heaven? Considerations in this article focus on the purposes of practical eschatology. This means that through the theological reflection on the concepts of ,a good man” and „to get to heaven" the article aims at offering the right answers, as well as formulating practical conclusions to shape the proper attitude towards life and eternity.

Keywords: Jesus Christ; eschatology; Heaven; good man; conscience 


\section{BIBLIOGRAFIA}

Benedykt XVI (2012): Gdy Bóg będzie «wszystkim we wszystkich». Rozważanie Ojca Świętego przed modlitwą Anioł Pański. https://opoka.org.pl/biblioteka/W/WP/benedykt_xvi/modlitwy/ ap_25112012.html [dostęp: 28.01.2019].

Benedykt XVI (2005): Homilia inauguracyjna. https://opoka.org.pl/biblioteka/W/WP/benedykt_ xvi/homilie/inauguracja_24042005.html [dostęp: 28.01.2019].

Benedykt XVI (2012): Radość wiary. Red. G. Vigini. Częstochowa.

Biblia Jerozolimska. (2006). Poznań.

Czy nie wystarczy być dobrym czlowiekiem? http://czybogistnieje.pl/czy-dobrzy-ludzie-zawsze-trafiaja-do-nieba/ [dostęp: 24.01.2019].

Czy to możliwe, żeby «dobrzy ludzie» mogli wylądować w piekle? https://www.kazdystudent.pl/a/ przyzwoici.html [dostęp: 24.01.2019].

Franciszek (2018): Adhortacja apostolska Gaudete et exsultate [GE]. https://opoka.org.pl/biblioteka/W/WP/franciszek_i/adhortacje/gaudete_19032018.html [dostęp: 12.02.2019].

Franciszek (2018): Messaggio del Santo Padre Francesco in occasione della XXIII Solenne Seduta Pubblica delle Pontificie Accademie. http://w2.vatican.va/content/francesco/it/messages/pontmessages/2018/documents/papa-francesco_20181204_messaggio-pontificie-accademie.html [dostęp: 24.01.2019].

Gądecki S., Jędraszewski M. (2016): Dekalog. Rozważania wygłoszone w ramach cyklu Verba Sacra z okazji 1050. Rocznicy Chrztu Polski. Poznań.

Grecko-polski Nowy Testament. Wydanie interlinearne z kluczem gramatycznym, z kodami Stronga i Popowskiego oraz petna transliteracja grecka tekstu. $\left(2017^{10}\right)$. Tłum. R. Popowski, M. Wojciechowski. Warszawa.

Harrington D.J. (2001): Ewangelia wedtug świętego Marka. W: R.E. Brown, J.A. Fitzmyer, R.E. Murphy (red), Katolicki komentarz biblijny s. 981-1033. Warszawa.

Karris R.J.: Ewangelia wedlug świętego Lukasza. W: R.E. Brown, J.A. Fitzmyer, R.E. Murphy (red.), Katolicki komentarz biblijny s. 1034-1107. Warszawa.

Katechizm Kościoła katolickiego. (1994) [KKK]. Poznań.

Keener C.S. (2000): Komentarz historyczno-kulturowy do Nowego Testamentu. Red. wyd. pol. K. Bardski, W. Chrostowski. Warszawa.

Kulik B. (2018): Czy jesteśmy naprawdę skazani na wieczność? Wieczność: życia, nieba i piekła. W: B. Kulik, W. Pałęcki (red.), Jest nadzieja, bo jest życie wieczne s. 127-147. Lublin.

Kupczak J.: Walter Kasper i Joseph Ratzinger o komunii dla osób rozwiedzionych $i$ w powtórnych zwiąkach. „Teologia i Moralność” 13: $2018 \mathrm{nr}$ 1(23) s. 39-60.

Leske A. (2000): Ewangelia wedlug św. Mateusza. W: W.R. Farmer (red.), Międzynarodowy komentarz do Pisma Świętego. Komentarz katolicki i ekumeniczny na XXI wiek s. 1133-1205. Warszawa.

da Lucca P. (1616): Dottrina del ben morire. Wenecja. https://books.google.pl/books?id=6sBQAAA AcAAJ\&pg=PA1\&hl=pl\&source=gbs_toc_r\&cad=3\#v=onepage\&q\&f=true [dostęp: 12.02.2019].

Machinek M. (2019): Dla kogo jest katolicki pogrzeb? http://uwm.edu.pl/tmor/index.php/2019/ 01/10/dla-kogo-jest-katolicki-pogrzeb/ [dostęp: 18.02.2019].

Mickiewicz F. (2012): Ewangelia wedlug św. Lukasza. Rozdziały 12-24. Wstęp, przekład z oryginatu, komentarz. W: A. Paciorek i in. (red.), Nowy komentarz biblijny. Nowy Testament. T. 3/2. Częstochowa.

Müller G.L. (2018): Przedmowa. Dlaczego adhortacja «Amoris Laetitia» może i powinna być rozumiana w sensie ortodoksyjnym. W: R. Buttiglione, Przyjacielska odpowiedź krytykom "Amoris Laetitia» s. 5-28. Kraków.

Müller G.L., Lisicki P. (2018): Chrystus jest zawsze nowoczesny. O Kościele, Zbawieniu, historii $i$ wspótczesności z Kardynałem Gerhardem L. Müllerem rozmawia Paweł Lisicki. Łomża. 
Nitrola A. (2010): Trattato di escatologia. T. 2. Pensare la venuta del Signore. Cinisello Balsamo. Milano.

Paciorek A. (2008): Ewangelia wedlug św. Mateusza. Rozdzialy 14-28. Wstęp, przektad z oryginalu, komentarz. W: A. Paciorek (red.), Nowy komentarz biblijny. Nowy Testament. T. 1/2. Częstochowa.

Pismo Święte Starego i Nowego Testamentu w przekładzie z języków oryginalnych ze wstępami i komentarzami (Biblia Poznańska). Nowy Testament. (1975). Oprac. zespół pod red. M. Petera i M. Wolniewicza. Poznań.

Pismo Święte Starego i Nowego Testamentu w przekładzie z języków oryginalnych (Biblia Tysiąclecia). $\left(2003^{5}\right)$. Oprac. Zespół Biblistów Polskich z inicjatywy Benedyktynów Tynieckich. Red. A. Jankowski, K. Romaniuk, L. Stachowiak, T. Hergesel, R. Rubinkiewicz. Poznań.

Pismo Święte Starego i Nowego Testamentu. Najnowszy przeklad z języków oryginalnych z komentarzem (Biblia Paulistów). (2009). Oprac. Zespół Biblistów Polskich z inicjatywy Towarzystwa Świętego Pawła. Częstochowa.

Popowski R. (19973): Wielki slownik grecko-polski. Wydanie z petna lokalizacja greckich haset, kluczem polsko-greckim oraz indeksem form czasownikowych. Warszawa.

Ratzinger J. (1995): Bóg Jezusa Chrystusa. Medytacje o Bogu Trójjedynym. Red. K. Tarnowski. Kraków.

Ratzinger J. (2014 a): Eschatologia - śmierć i życie wieczne. W: K. Góźdź, M. Górecka (red.), Zmartwychwstanie $i$ życie wieczne. Studia o eschatologii i teologii nadziei (Opera Omnia. T. 10.) s. 25-257. Lublin.

Ratzinger J.( 2014 b): Niebo. W: K. Góźdź, M. Górecka (red.), Zmartwychwstanie i życie wieczne. Studia o eschatologii i teologii nadziei (Opera Omnia. T. 10.) s. 305-308. Lublin.

Ratzinger J. (2013): Poza Kościołem nie ma zbawienia? W: K. Góźdź, M. Górecka (red.), Kościótznak wśród narodów. Pisma eklezjologiczne i ekumeniczne (Opera Omnia. T. 8/2.) s. 975-999. Lublin.

Ratzinger J. (1996): Wprowadzenie w chrześcijaństwo. Kraków.

Romaniuk K., Jankowski A., Stachowiak L. (1999): Komentarz praktyczny do Nowego Testamentu. T. 1. Poznań-Kraków.

Ryś G. (2016): Moc Stowa. Kraków.

Sobór Watykański II: Konstytucja dogmatyczna o Kościele Lumen Gentium [LG]. http://ptm. rel.pl/czytelnia/dokumenty/dokumenty-soborowe/sobor-watykanski-ii/113-konstytucjadogmatyczna-o-kosciele-lumen-gentium.html [dostęp: 29.12.2019].

Stählin G. (1957): $\mu \tilde{v} \theta$ o५. W: G. Kittel (red), Theologisches Wörterbuch zum Neuen Testament s. 769-803. Stuttgart.

Szymik S. (2018): «Kto wierzy, ma życie wieczne» (J 6,47). Wiara w Jezusa Chrystusa warunkiem zbawienia i życia wiecznego. W: B. Kulik, W. Pałęcki (red.), Jest nadzieja, bo jest życie wieczne s. 15-30. Lublin.

Turnau J. (2019): Czy człowiek niewierzacy, ale dobry może trafić do nieba? Wyjaśnia Jan Turnau, http://wyborcza.pl/10,155167,22694939,czy-czlowiek-niewierzacy-ale-dobry-moze-trafic-donieba-wyjasnia.html?disableRedirects=true [dostęp: 24.01.2019].

BogDAN KULIK - ks. dr, Misjonarz Świętej Rodziny, wykładowca teologii dogmatycznej Wyższego Seminarium Duchownego Misjonarzy Świętej Rodziny w Kazimierzu Biskupim oraz Wydziału Teologicznego Uniwersytetu im. Adama Mickiewicza w Poznaniu; e-mail: kulikbogdan@op.pl. 